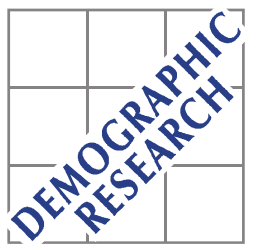

Demographic Research a free, expedited, online journal

of peer-reviewed research and commentary in the population sciences published by the Max Planck Institute for Demographic Research

Konrad-Zuse Str. 1, D-18057 Rostock · GERMANY

www.demographic-research.org

DEMOGRAPHIC RESEARCH

VOLUME 19, ARTICLE 53, PAGES 1811-1830

PUBLISHED 10 OCTOBER 2008

http://www.demographic-research.org/Volumes/Vol19/53/

DOI: 10.4054/DemRes.2008.19.53

Research Article

Polygyny and HIV in Malawi

Georges Reniers

Rania Tfaily

This publication is part of the proposed Special Collection "HIV/AIDS in subSaharan Africa”, edited by Susan Watkins, Jere Behrman, Hans-Peter Kohler, and Simona Bignami-Van Assche.

(C) 2008 Reniers \& Tfaily.

This open-access work is published under the terms of the Creative Commons Attribution NonCommercial License 2.0 Germany, which permits use, reproduction \& distribution in any medium for non-commercial purposes, provided the original author(s) and source are given credit.

See http:// creativecommons.org/licenses/by-nc/2.0/de/ 


\section{Table of Contents}

1 Background 1812

2 Data 1813

3 Polygyny and HIV prevalence in Malawi 1815

$4 \quad$ Polygyny and adultery 1819

5 Selection of HIV positive women into polygynous unions 1822

$\begin{array}{lll}6 & \text { Discussion } & 1825\end{array}$

$7 \quad$ Acknowledgements 1826

$\begin{array}{ll}\text { References } & 1827\end{array}$ 


\title{
Polygyny and HIV in Malawi
}

\author{
Georges Reniers ${ }^{1,2}$ \\ Rania Tfaily $^{3}$
}

\begin{abstract}
We review the relationship between polygyny and HIV and identify a positive individual-level correlation, and a negative ecological correlation. We subsequently examine two mechanisms that contribute to the individual-level correlation. First, we find that men in polygynous marriages have more extramarital sex than men in monogamous unions (both in terms of self reports and in terms of spousal reports of the suspicion of adultery). Second, we find evidence of adverse selection of HIV positive women into polygynous unions via an investigation of the relationship between marriage order and polygyny status. We conclude with reflections about possible explanations for the distinct individual and ecological correlations.
\end{abstract}

\footnotetext{
${ }^{1}$ University of Colorado at Boulder, Population Program, Institute of Behavioral Science.

${ }^{2}$ University of the Witwatersrand, School of Social Sciences and School of Public Health.

${ }^{3}$ Carleton University, Department of Sociology and Anthropology.
} 


\section{Background}

In early scientific, policy, and popular discourses around HIV/AIDS, polygyny often features as a cultural practice that facilitates the spread of the epidemic (Gausset 2001; Oppong and Kalipeni 2003). The association between polygyny and HIV, however, is not very often empirically verified. In theory, there are several plausible reasons why polygyny may contribute to the spread of HIV. First, polygynous marriages involve multiple partners, each of whom might introduce HIV into the household. Once one of the spouses is or becomes HIV positive, the others are also exposed to HIV. The simultaneous nature of partnerships in polygynous unions is likely to have an independent effect on the spread of the virus (net of the quantum of partnerships): under serial monogamy earlier partners are not at risk of being infected by later partners; in concurrent relationships, the protective effect of the sequence is lost (Morris and Kretzschmar 1997). Concurrency of partnerships is considered particularly important for HIV because the probability of transmitting the virus is highest in the period immediately following seroconversion (Morris and Kretzschmar 1997; Wawer, et al. 2005). ${ }^{4}$ Second, men in societies where polygyny is practiced tend to marry at a later age and more often have casual sexual partnerships in early adulthood (Caldwell, et al. 1993; Philipson and Posner 1995). Third, the institution of polygyny presumably endorses the belief that men require more than one woman for sexual satisfaction (Caldwell, et al. 1993). Fourth, polygynous societies are often also characterized by high rates of marital dissolution and the easy remarriage of widows and divorcees (Goldman, et al. 1989; Halton, et al. 2003; Hertrich 2006; Pison 1986; Van de Walle 1990). This may lead to an increase in the total number of sexual partners over a man's or a woman's lifetime.

On the other hand, it is sometimes argued that polygyny contains the spread of HIV because it limits the incidence of extra-marital sex (Caldwell, et al. 1993; Carael, et al. 2001; Mitsunaga, et al. 2005). ${ }^{5}$ The empirical evidence for that is mixed. Two

\footnotetext{
${ }^{4}$ The empirical evidence for a concurrency effect on the spread of HIV and other STDs is, however, mixed. In a study on the spread of Herpes Simplex, Halton and colleagues found that the risk of infection was as high in women whose husbands were polygynous as in those whose husbands had a prior marriage (Halton, et al. 2003). This suggests that it is the number of partners one has had, and not necessarily the concurrency of these relationship that affects the spread of STDs. This was also suggested by Lagarde and colleagues who were not able to show that concurrency of sexual partnerships facilitates the spread of HIV (Lagarde, et al. 2001). Convincing evidence for a concurrency effect on HIV incidence and prevalence in the Rakai district in rural Uganda could not be found either (Kelly 2001). In a study on Chlamydia transmission in Colorado, however, concurrency was identified as the most powerful predictor of transmission (Potterat, et al. 1999).

${ }^{5}$ A greater permissiveness of extra-marital sex is sometimes associated with the practice of prolonged postpartum abstinence (Cleland, et al. 1999; Orubuloye, et al. 1997). Men in polygynous unions, however, could change partners within marriage, and thus have less of an incentive to engage in non-marital sex than monogamous men (Cleland, et al. 1999; Van de Walle 1990).
} 
studies found partial evidence that men (and women) in polygynous unions have more extra-marital affairs than their counterparts in monogamous marriages (Carael, et al. 2001; Mitsunaga, et al. 2005). A study in Tanzania suggests that non-marital partnerships are less common among polygynous men and more frequent among women in polygynous unions (Nnko, et al. 2004).

In this article, we study the relationship between polygyny and HIV infection in rural Malawi and try to disentangle the process that leads to different infection rates in polygynous and monogamous unions. We first describe the relationship between polygyny and HIV, and find that HIV prevalence is higher among those in polygynous compared to monogamous unions. With that in mind, we investigate two mechanisms that could lead to higher prevalence rates in men and women who are in polygynous unions: (1) partners in polygynous unions have more extra-marital relationships and thus increase each other's exposure to HIV; (2) women who are recruited into a polygynous union are more likely to be HIV positive than those who marry a monogamous husband. In addition to these two mechanisms, variation in HIV prevalence rates by union type is also possibly due to a 'polygyny-effect', or, in other words, due to the fact that individuals in polygynous unions are part of a sexual network with concurrent partnerships.

We study the first of these hypotheses using reports of spousal infidelity and assess whether extra-marital sexual relationships are higher in polygynous compared to monogamous unions. To test the second hypothesis we need to investigate selection of spouses into polygynous marriages based on their HIV status. Because the sample size and number of HIV positive cases is too small to permit such an analysis, we focus instead on two risk factors of HIV, namely widowhood and marriage order. We thus investigate whether widows are more often selected into polygynous unions than divorcees and analyze whether marriage order correlates with selection into a polygynous marriage. Both multiple marriages and widowhood are considered risk factors for being HIV positive; an assumption for which we provide some evidence as well.

\section{Data}

We use data from the adult samples of the Malawi Diffusion and Ideational Change project (MDICP). These are longitudinal survey data collected in the rural areas of three districts with approximately 1,500 ever-married women and their husbands who have 
been interviewed in 1998 (MDICP1), in 2001 (MDICP2) and 2004 (MDICP3). ${ }^{6}$ In 2004 respondents were counseled and tested for $\mathrm{HIV}^{7} \mathrm{HIV}$ prevalence in the sample is 9.3 percent for women (95\%-CI: 7.6-11.3) and 6.4 percent for men (95\%-CI: 4.6-8.7). Unless stated otherwise, we rely on retrospectively reported marriage histories collected as part of MDICP2. For each respondent, these histories contain information on the present (or most recent if not currently married), previous and first marriage. This means that the marriage histories are incomplete for those who married more than three times. This is not of great importance because only five and two percent of men and women, respectively, have incomplete marriage histories. The dataset has information on the beginning, duration and outcome of marriages, as well as on a number of marriage characteristics such as the residence pattern during marriage, the age difference between spouses, whether or not the husband is or was polygynous, and whether there was any suspicion of spousal adultery. ${ }^{8}$ From these histories, we created a dataset of marriages that will be used in several of the analyses that are presented below. Compared to DHS surveys or censuses, which typically provide information on current status, this is an exceptionally rich data source because it gives an insight into the marriage trajectories rather than a snapshot in time. Retrospective reporting, however, may be subject to bias because of the problematic reporting of ages and dates, the ex post facto rationalization of decision-making processes, and possibly because of a greater propensity to omit short unsuccessful unions from marriage histories as time passes. Retrospective reporting also implies that the information is confined to those who survived and were present at the time of the survey.

The sample is ethnically and religiously heterogeneous. Rumphi in the north is characterized by a predominantly patrilineal system of descent with patrilocal residence after marriage. The ethnic groups in Balaka in the south follow a matrilineal system of filiation, and residence after marriage is most often matrilocal. In Mchinji, in the center of the country, descent is less rigidly matrilineal, and residence may be either matrilocal or patrilocal. The southern district is predominantly Muslim; Christians are in the majority in the other two areas. The Tumbuka are the main ethnic group in Rumphi, the

\footnotetext{
${ }^{6}$ A description of the project, survey instruments and data is available at http://www.malawi.pop.upenn.edu, and in a special collection of Demographic Research (Watkins, et al. 2003). Bignami et al (2003) report on data quality and sample attrition.

${ }^{7}$ The testing protocol is summarized in Bignami et al. (2004), response rates are discussed in Obare et al. (Forthcoming).

${ }^{8}$ Marriage outcome (if ended) is defined as either divorced or widowed. Separation is very rare and combined with the category 'divorced'. The measure of polygyny used in this article is based on two questions: (1) whether or not the husband (or respondent if male) had any other wives at the time of marriage, and (2) whether the husband (or respondent) married an additional wife (or wives) during the marriage under consideration. A marriage is considered polygynous if any of those two questions was answered affirmatively. The measure of suspected adultery is clarified in section 4 .
} 
Chewa in Mchinji, and the Yao in Balaka. Because of this cultural heterogeneity, we control for district in most of our statistical models.

Marriage in Malawi is quasi-universal but divorce rates are high, with some variation across the three research sites: in the south, over 50 percent of first marriages dissolve within 15 years and in the two other districts, this figure is between 30 and 40 percent. Part of this discrepancy is related to the matrilineal system of filiation that predominates in most southern ethnic groups wherein marriage dissolution is traditionally higher (Reniers 2003).

\section{Polygyny and HIV prevalence in Malawi}

There are quite important regional differences in the level of polygyny. The percentage of married women with one or more co-wives, and the percentage of married men with more than one spouse are highest in the north and lowest in the southern region (Table 1). For a number of reasons, the indices of polygyny in the sample are higher than those reported in the 2004 Demographic and Health Survey (DHS) (NSO and ORC Macro 2005). First, the MDICP sample is drawn from exclusively rural settings where polygyny levels are generally higher. Second, in MDCIP1 the sampling frame consisted of ever-married women and their husbands. In MDICP2 other and new spouses of already sampled men and women were also interviewed, thereby increasing the share of women married to a polygynous husband. Third, the measure of polygyny in the DHS reflects current status, whereas the definition used here categorizes a marriage as polygynous when the husband had another wife at any time during the marriage under consideration (see also footnote 5). Fourth, the MDICP data pertain to all (i.e., current, previous and first) marriages of men and women in the sample. If polygyny levels have declined over time, the polygyny indices reported in Table 1 should be lower in the Malawi DHS compared to MDICP data because the DHS only contains information on the current marriage. ${ }^{9}$ Rather than a nuisance, however, the over-representation of polygynous marriages in our sample is a convenient statistical feature because it increases the power of statistical tests.

\footnotetext{
${ }^{9}$ As shown in Table 1, the percentage of women with one or more co-wives declined between 1992 and 2004, while the decline in the percentage of polygynous men during the same period was modest or non-existent. In van de Walle's (Van de Walle 1968) terminology this suggests a decline in the intensity of polygyny (i.e., a decrease in the average number of wives of each polygynyst) rather than a decline in the incidence of polygyny (i.e., the proportion of married men with more than one wife). A decline in the fraction of women with co-wives has been reported for several (not all) African countries (Antoine 2002; Westoff 2003).
} 
Table 1: Prevalence of polygyny and HIV in the three regions of the DHS survey and sample districts of the MDICP (in percent)

\begin{tabular}{|c|c|c|c|}
\hline & \multicolumn{3}{|c|}{ DHS $^{\text {a }}$} \\
\hline & South & Central & North \\
\hline \multicolumn{4}{|l|}{ Percentage of currently married women with one or more co-wives } \\
\hline 1992 & 17.2 & 22.7 & 28.3 \\
\hline 2004 & 12.8 & 15.5 & 25.9 \\
\hline \multicolumn{4}{|l|}{ Percentage of currently married men with more than one spouse } \\
\hline 1992 & 4.7 & 12.6 & 14.9 \\
\hline 2004 & 6.1 & 11.3 & 20.7 \\
\hline \multirow[t]{3}{*}{ HIV prevalence (both sexes), 2004} & 17.6 & 6.5 & 8.1 \\
\hline & \multicolumn{3}{|c|}{ MDICP } \\
\hline & Balaka & Mchinji & Rumphi \\
\hline $\begin{array}{l}\text { Percentage of marriages in which the respondent (women's } \\
\text { reports) had one or more co-wives at any time during her marriage }\end{array}$ & 31.7 & 36.9 & 50.7 \\
\hline $\begin{array}{l}\text { Percentage of marriages in which the respondent (men's reports) } \\
\text { had more than one wife at any time during his marriage }\end{array}$ & 23.8 & 29.4 & 45.0 \\
\hline HIV prevalence (both sexes) & 10.6 & 9.1 & 5.7 \\
\hline
\end{tabular}

a Sources: NSO and ORC Macro (1994; 2005)

In terms of HIV prevalence, the levels in the DHS sample are higher than those in the MDICP. This is mainly because the latter pertain to an exclusively rural population. The central region is an exception, and that is possibly due to the uncharacteristically high refusal rates in the DHS survey in the central region (particularly in Lilongwe where less than 40 percent of the respondents were tested) (NSO and ORC Macro 2005). Polygyny is most common in the district (Rumphi) where HIV infection rates are the lowest. In Balaka, where HIV prevalence is the highest, polygyny is least common. At the aggregate level, polygyny thus negatively correlates with HIV prevalence. At the individual level the association is positive: ${ }^{10}$ the odds for being HIV positive are 2.58 times (95\%-CI: 1.34 - 4.94) higher among men who have ever been in

\footnotetext{
${ }^{10}$ A similar, albeit reversed, disparity has previously been identified for the relationship between polygyny and fertility (Ezeh 1997; Pebley and Mbugua 1989): these studies have found that women in polygynous unions tend to have lower fertility than women in monogamous unions, but populations that practice polygyny usually have higher fertility rates compared to populations where polygyny is uncommon.
} 
a polygynous union than among men who have not had any concurrent spouses. The corresponding value for women is 2.00 (95\%-CI: 1.30 - 3.08). ${ }^{11}$

These differences persist after controlling for district and age (Table 2, model 1). This is particularly so for polygynous men who are about three times more likely to be HIV positive than monogamously married men. The odds for being HIV positive are significantly higher among women who have been -or still are- married to polygynous husbands compared to women who have been in unions with monogamous husbands only. That relationship appears to be stronger for second and third wives than for first wives, but the differences are not statistically significant $(\mathrm{p}=0.18)$ and omitted from the final model.

One of the mechanisms that could produce a difference in HIV prevalence rates in polygynous and monogamous unions is a difference in the number of marriages. To test whether this has an effect on HIV status and to verify whether it absorbs some of the variance in HIV prevalence attributed to polygyny, we introduce marriage order as an additional explanatory variable in the analyses. For women, having been married more than once correlates significantly with HIV status, and reduces the effect of having ever been in a polygynous marriage. Controlling for marriage order entirely absorbs the effect -if any- of wife's rank (not shown). The parameter estimates for the polygyny variable, however, remain significant, and that implies that marriage order alone cannot explain the variance in prevalence rates by polygyny status. ${ }^{12}$

The test is less straightforward for men because polygyny implies multiple partners by definition. In their case, we compare prevalence rates for those who are or have been in precisely two formal unions and those who are or have been in at least three marriages. The effects are of a similar magnitude as for women, but not statistically significant; perhaps because the small sample size limits statistical power.

\footnotetext{
${ }^{11}$ This positive association is also reproduced for each of the three districts separately. For men the relationship is only statistically significant for Mchinji. There are, however, only 40 HIV positive men in the sample and that contributes to the low statistical power of the tests. In the MDHS, the odds that a polygynous man (current status) tested positive are lower than those for a monogamous man, but these values are not statistically significant (OR: 0.65, 95\%-CI: 0.39 - 1.14). For women, the value is closer to what we find in the MDICP sample and statistically significant (OR: 1.49, 95\%-CI: 1.08 - 2.06) (NSO and ORC Macro 2005).

${ }^{12}$ Marriage order is strongly associated with the probability of marrying a polygynous husband (which ranges from 34.81 percent for women in their first marriages to 76.60 percent for women in third or higher order marriages). Marriage order is also correlated with the probability of becoming a second (or higher orderranked) wife of a polygynous husband (from 12.85 percent for women in first marriages to 56.03 percent for those in second or higher order marriages) (not shown). This finding concurs with earlier reports that first and higher order wives of polygynous husbands often have diverging characteristics (Timæus and Reynar 1998).
} 
Table 2: $\quad$ Risk factors of HIV+ status (odds ratios)

\begin{tabular}{|c|c|c|c|c|}
\hline & \multicolumn{2}{|c|}{ Women } & \multicolumn{2}{|c|}{ Men } \\
\hline & Model 1 & Model 2 & Model 1 & Model $2^{a}$ \\
\hline \multicolumn{5}{|l|}{ District (vs Balaka) } \\
\hline \multirow[t]{2}{*}{ Mchinji } & 0.773 & 0.955 & 1.196 & $2.882^{\star *}$ \\
\hline & $(1.01)$ & $(0.17)$ & $(0.46)$ & $(2.13)$ \\
\hline \multirow[t]{2}{*}{ Rumphi } & $0.495^{\star \star \star}$ & 0.743 & $0.460^{*}$ & 1.422 \\
\hline & $(2.58)$ & $(1.01)$ & $(1.74)$ & $(0.65)$ \\
\hline \multirow[t]{2}{*}{ Age } & $1.230^{*}$ & 1.172 & $1.410 * \star$ & $1.455^{\star}$ \\
\hline & $(1.91)$ & $(1.45)$ & $(2.02)$ & $(1.72)$ \\
\hline \multirow[t]{2}{*}{ Age squared } & $0.997^{\star \star}$ & $0.997^{*}$ & $0.996^{\star \star}$ & $0.995^{*}$ \\
\hline & $(2.25)$ & $(1.93)$ & $(2.11)$ & $(1.87)$ \\
\hline \multirow[t]{2}{*}{ Ever polygynous } & $2.301^{\star \star \star}$ & $1.670^{\star *}$ & $3.142^{\star \star \star}$ & 1.568 \\
\hline & (3.63) & $(2.10)$ & $(3.26)$ & $(1.07)$ \\
\hline \multicolumn{5}{|c|}{ Marriage order (vs 1st marriage) } \\
\hline \multirow[t]{2}{*}{ Second } & & $2.258^{\star \star \star}$ & & ref $^{a}$ \\
\hline & & (3.08) & & \\
\hline \multirow[t]{2}{*}{$>$ Second } & & $4.292^{* * *}$ & & 1.895 \\
\hline & & $(4.24)$ & & $(1.51)$ \\
\hline N (respondents) & 1043 & 1043 & 621 & 306 \\
\hline LL & -306.69 & -296.85 & -137.83 & -90.09 \\
\hline df & 5 & 7 & 5 & 6 \\
\hline Pseudo $\mathrm{R}^{2}$ & 0.05 & 0.08 & 0.07 & 0.08 \\
\hline
\end{tabular}

Source: Malawi Diffusion and Ideational Change Project (MDICP2)

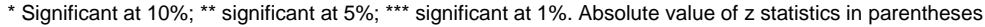

${ }^{a}$ For men, marriage order is defined irrespective of the outcome of the previous marriage. Analysis pertains to higher order marriages only. The second marriage is the reference category.

So far, we have presented evidence that HIV prevalence rates are higher in polygynous unions, and this does not seem to be a simple function of the respondent's number of formal unions. In what follows we investigate two processes that could lead to higher HIV prevalence in men and women in polygynous unions, namely differences in (risky) sexual behavior between men and women in monogamous and polygynous unions and the adverse selection of HIV positive women into polygynous unions. 


\section{Polygyny and adultery}

To test the association between polygyny and risky sexual behavior, we compare the frequency of extra-marital sex in monogamous and polygynous unions. To do so we rely on self reports of adultery and on spousal reports of -the suspicion of- adultery. The suspicion of adultery was operationalized via the survey question: "During your time together, did/do you suspect or know that your husband/wife had/has sexual relations with other women/men apart from you". Women of polygynous men were told that this did not include co-wives. ${ }^{13}$ The suspicion of spousal infidelity is reported by women in 33.2 percent of the marriages and by men in 14.5 percent of the marriages. Self-reports of adultery are lower: men report extra-marital affairs in 19.5 percent of the marriages and women only in 2.5 percent of the cases. These percentages are virtually the same if the analysis is restricted to first marriages only.

The statistical model that we use to test the association between polygyny and adultery is a binary logistic regression where reported (suspicion of) adultery is the outcome. We do this for both men (Table 3) and women (Table 4). Men who are in polygynous marriages are 50 percent more likely to self-report extra-marital affairs than men in monogamous unions, an effect that remains stable after controlling for demographic, socioeconomic, and residence variables. The odds that women in polygynous marriages suspect their husband of infidelity are about three times the odds of women in monogamous unions. The effect becomes even stronger after controlling for demographic and residency variables.

In terms of the control variables, we find that reports of male adultery decline with an increasing age at marriage. The effect of marriage period suggests that adultery has decreased over time (Reniers 2008). Educated men are about 66 percent more likely to self-report infidelity than their uneducated counterparts, but education does not seem to matter for spousal reports of adultery. Having a spouse who lives in the same village is negatively associated with reports of adultery. This probably indicates that adultery is a matter of opportunity and social control. Because its effect is only significant for spousal reports of adultery and not self-reports, it may also be due to women's uncertainty about the behavior of absent spouses. Regardless of the effects of these controls, the main conclusion from this analysis remains that polygynous men more often have extra-marital affairs (measured via self reports as well as reports by their spouses), which could contribute to the difference in HIV prevalence rates between individuals in polygynous and monogamous unions.

\footnotetext{
${ }^{13}$ Unfortunately, the survey instructions did not include explicit guidelines for coding sex with women who were to become future wives.
} 
Reniers \& Tfaily: Polygyny and HIV in Malawi

Table 3: $\quad$ Predictors of adultery (odds ratios), men

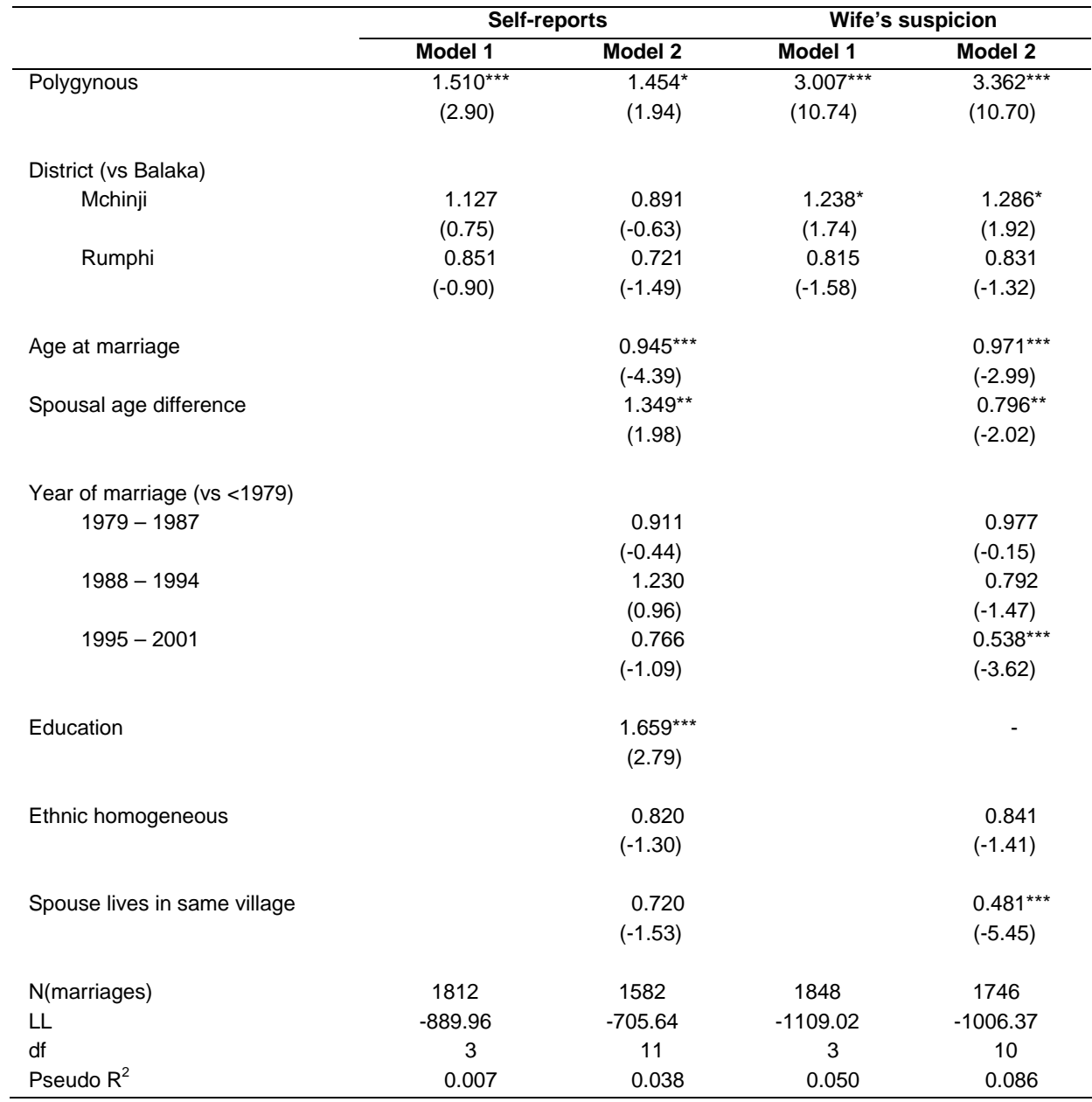

Source: Malawi Diffusion and Ideational Change Project (MDICP2)

* Significant at 10\%; ** significant at 5\%; ** significant at 1\%. Robust z statistics in parentheses (adjusted for clustering on respondent)

Variable definitions: age at marriage: age at the beginning of the marriage (in the analysis of self-reports, the age at marriage refers to the husbands age at marriage; in the analysis where we use the wife's suspicion of the husband's adultery, the value of the age at marriage pertains to the wife. Because the ages of spouses are positively correlated, the interpretation of the effects in the two cases is similar); spousal age difference: husband is more than five years older than his wife versus less than that (reference category); year of marriage: calendar year at the start of the marriages; education: a minimum of three years of education versus less than that (reference category); ethnic homogenous marriages: unions where both spouses are of the same ethnicity versus couples where the spouses are of a different ethnicity (reference category); spouse lives in same village or not (reference category). 
For women there does not seem to be any substantial difference in extra-marital relationships between those in polygynous and monogamous unions: although the parameter values point in the same direction as those for men, they are smaller and lack statistical significance (Table 4). In Balaka, where the Yao follow a predominantly matrilineal system of decent, the reports of female adultery are higher than in the other two districts. This is consistent with anthropological commentary that women in matrilineal groups exercise greater control over their sexuality and offspring (Caldwell, et al. 1992). The other factors influencing infidelity among women are quite similar to those for men: educated women are more likely to self-report extra-marital affairs than their less educated counterparts, and reports of adultery are less common in recent marriages, and when partners co-residence in the same village. Combined, Tables 3 and 4 thus provide evidence that polygynous men (but not women) are more likely to engage in risky sexual behavior than monogamously married men and thus increase their own as well as their spouses' risk of HIV infection.

\section{Table 4: Predictors of adultery (odds ratios), women}

\begin{tabular}{|c|c|c|c|c|}
\hline & \multicolumn{2}{|c|}{ Self-reports } & \multicolumn{2}{|c|}{ Husband's suspicion } \\
\hline & Model 1 & Model 2 & Model 1 & Model 2 \\
\hline \multirow[t]{2}{*}{ Polygynous } & 1.285 & 1.229 & 0.887 & 1.283 \\
\hline & $(0.84)$ & $(0.59)$ & $(-0.73)$ & (1.31) \\
\hline \multicolumn{5}{|l|}{ District (vs Balaka) } \\
\hline \multirow[t]{2}{*}{ Mchinji } & $0.347^{\star \star \star}$ & $0.371^{\star \star}$ & 0.854 & 0.925 \\
\hline & $(-2.62)$ & $(-2.55)$ & $(-0.91)$ & $(-0.41)$ \\
\hline \multirow[t]{2}{*}{ Rumphi } & $0.350^{* *}$ & $0.228^{\star \star \star}$ & $0.684^{\star *}$ & $0.706^{*}$ \\
\hline & $(-2.37)$ & $(-3.10)$ & $(-2.06)$ & $(-1.75)$ \\
\hline \multirow[t]{2}{*}{ Age at marriage } & & 1.044 & & 0.981 \\
\hline & & $(1.31)$ & & $(-1.62)$ \\
\hline \multirow[t]{2}{*}{ Spousal age difference } & & 1.304 & & 0.985 \\
\hline & & $(0.78)$ & & $(-0.09)$ \\
\hline \multicolumn{5}{|c|}{ Year of marriage (vs <1979) } \\
\hline \multirow[t]{2}{*}{$1979-1987$} & & 0.646 & & 0.794 \\
\hline & & $(-1.03)$ & & $(-1.10)$ \\
\hline \multirow[t]{2}{*}{$1988-1994$} & & $0.249^{\star \star}$ & & 0.905 \\
\hline & & $(-2.56)$ & & $(-0.50)$ \\
\hline \multirow[t]{2}{*}{$1995-2001$} & & 0.565 & & $0.491^{\star \star \star}$ \\
\hline & & $(-0.99)$ & & $(-2.87)$ \\
\hline Education & & $\begin{array}{l}1.927^{\star} \\
(1.85)\end{array}$ & & - \\
\hline
\end{tabular}


Table 4: (continued)

\begin{tabular}{lcccc}
\hline & \multicolumn{2}{c}{ Self-reports } & \multicolumn{2}{c}{ Husband's suspicion } \\
\cline { 2 - 5 } & Model 1 & Model 2 & Model 1 & Model 2 \\
\hline Ethnic homogeneous & & 1.062 & 1.041 \\
& & $(0.17)$ & & $(0.25)$ \\
Spouse lives in same village & & & & \\
& & $0.284^{\star \star \star}$ & & $0.477^{\star \star *}$ \\
N(marriages) & & $(-4.25)$ & & $(-3.80)$ \\
LL & 1977 & 1861 & 1712 & 1497 \\
df & -208.64 & -175.70 & -707.01 & -607.66 \\
Pseudo $\mathrm{R}^{2}$ & 3 & 11 & 3 & 10 \\
\hline
\end{tabular}

Source: Malawi Diffusion and Ideational Change Project (MDICP2)

* Significant at $10 \%$; ** significant at $5 \%$; *** significant at $1 \%$. Robust $\mathrm{z}$ statistics in parentheses (adjusted for clustering on respondent)

Variable definitions: see table 3

\section{Selection of HIV positive women into polygynous unions}

A direct assessment of the selection of HIV positive women into polygynous unions requires a measure of HIV status for all women at the time of marriage. Unfortunately, these data are not available. Instead, we examine selection processes with respect to characteristics that are measurable and that correlate with HIV status. One of them is widowhood, and we therefore compare the likelihood that widows and divorcees become part of a polygynous union. The odds for being HIV positive are about 78 percent higher $(\mathrm{p}=.12)$ for a widow than for a divorcee (controlling for district and age). ${ }^{14}$ Adding an additional control for having been in a polygynous union barely changes that relationship. For adverse selection into polygynous marriages to account for (part of) the difference in HIV prevalence rates between polygynous and monogamous households, women whose previous husband(s) died should be disproportionately found in marriages with a polygynous husband. ${ }^{15}$

The other predictor that we consider is marriage order. Here we postulate that marriage order correlates with HIV status (see Table 2), and that women at higher order marriages are disproportionately recruited into marriages with polygynous men. In

\footnotetext{
${ }^{14}$ In the 2004 Malawi DHS, HIV prevalence among the widowed (current status) was 35.5 percent $(\mathrm{N}=103)$ and 23.3 percent among the divorced and separated ( $\mathrm{N}=272)$ (NSO and ORC Macro 2005).

${ }^{15}$ In a different study, remarriage rates of widows were found to be lower than those of divorcees (particularly in the 1990s), most likely because an increasing share of widows are surviving spouses of AIDS victims and therefore not very attractive marriage partners (Reniers 2008). In this article, we are merely interested in explaining differences in HIV prevalence by marriage type. The analysis therefore conditions on remarriage.
} 
these analyses we define a polygynous husband as someone who had at least one other spouse at the time of marriage. The tests for both of these selection processes are carried out by means of a binary logistic regression model whereby the marriage type is the outcome of interest and widowhood (versus divorced status, Table 5, model 1) and marriage order (Table 5, model 2) are the predictors.

In addition to our earlier finding that the prevalence of polygyny varies by district, we learn from Table 5 that the frequency of polygynous marriages increases with women's age at marriage: the older a woman, the more likely she is to marry a polygynist. The quadratic effect for age at marriage indicates that the odds of marrying a polygynous husband follow a curvilinear pattern with an inflection point around age 36. Widows are, as expected, more likely to remarry a polygynous husband, but the effect is relatively small and not statistically significant. ${ }^{16}$

The effect of marriage order is much stronger and highly significant: the odds that a woman will marry a polygynous husband are about three times higher in a second marriage than in a first marriage, and the association gains strength with marriage order. Interestingly, marriage order is also a better predictor of HIV status than widowhood (when compared to divorce). In these analyses, we thus find support for the proposition that HIV positive women are more likely to be selected into polygynous marriages than monogamous unions.

\footnotetext{
${ }^{16}$ The lack of a strong effect is also an indication that levirate or widow inheritance is probably not very important in Malawi (at least not to the extent that it would lead to noticeable differences between widows and divorcees in their likelihood of remarrying a polygynous husband). Because levirate is uncommon in ethnic groups with matrilineal descent systems, we tested for an interaction (not statistically significant) between widowed and district.
} 
Reniers \& Tfaily: Polygyny and HIV in Malawi

Table 5: Characteristics affecting marriage to a polygynous husband (women only, odds ratios)

\begin{tabular}{|c|c|c|}
\hline & Model $1^{\mathrm{a}}$ & Model 2 \\
\hline \multicolumn{3}{|l|}{ District (vs Balaka) } \\
\hline \multirow[t]{2}{*}{ Mchinji } & 1.179 & $1.460^{* * *}$ \\
\hline & $(0.90)$ & $(2.67)$ \\
\hline \multirow[t]{2}{*}{ Rumphi } & $3.101^{\star \star \star}$ & $2.826^{\star \star \star}$ \\
\hline & $(5.42)$ & $(7.38)$ \\
\hline \multirow[t]{2}{*}{ Age at marriage } & $1.259 * \star \star$ & $1.244^{\star \star *}$ \\
\hline & (3.18) & $(4.11)$ \\
\hline \multirow[t]{2}{*}{ Age at marriage squared } & $0.997^{\star \star \star}$ & $0.997^{\star \star \star}$ \\
\hline & $(2.75)$ & $(3.41)$ \\
\hline \multirow[t]{2}{*}{ Widow (vs divorcee) } & 1.21 & \\
\hline & $(0.88)$ & \\
\hline \multicolumn{3}{|c|}{ Marriage order (vs 1st marriage) } \\
\hline \multirow[t]{2}{*}{ Second } & & $2.781^{\star * *}$ \\
\hline & & $(6.36)$ \\
\hline \multirow[t]{2}{*}{$>$ Second } & & $3.500^{\star \star *}$ \\
\hline & & $(5.16)$ \\
\hline $\mathrm{N}$ (marriages) & 705 & 2232 \\
\hline LL & -449.83 & -1037.08 \\
\hline df & 5 & 6 \\
\hline Pseudo $\mathrm{R}^{2}$ & 0.06 & 0.13 \\
\hline
\end{tabular}

Source: Malawi Diffusion and Ideational Change Project (MDICP2)

* Significant at 10\%; ** significant at 5\%; ** significant at 1\%. Robust z statistics in parentheses (adjusted for clustering on respondent)

${ }^{a}$ Analysis pertains to higher order marriages only

Variable definitions: Age at marriage: age at marriage of the respondent (i.e., the wife); widow: whether the woman's previous marriage ended in widowhood or divorce/separation; Marriage order: $1^{\text {st }}$ marriage (reference category), $2^{\text {nd }}$ marriage, or higher order marriage of the wife.

Models selection: The interaction between marriage period and outcome of the previous marriage is insignificant (indicating no significant change in the selection of widows into polygynous unions over time). The interaction effect between marriage period and marriage order seems to suggest that women in their third marriage or above are selected into polygynous households more often in the 1990s than was the case before that period. This effect, however, does not reach statistical significance either $(z=1.04)$. Both interactions are omitted from the final model. 


\section{Discussion}

We began with the observation that HIV prevalence rates in Malawi are higher among those who have been in a polygynous union compared to those who have been in monogamous marriages only. We proposed and tested two mechanisms that could produce such a difference and found evidence for each of those processes. First, polygynously married men more often engage in extra-marital affairs than monogamous men, a result that holds for both self-reports and spousal suspicion of adultery. For women, the evidence points in a similar direction but does not reach the same level of statistical significance. Our data do not allow us to investigate why polygynous men are presumably less faithful than monogamous men. Possible explanations are that these men have a greater disposition for multiple partners, that they are searching for new spouses, or, that they experience less objection from their current wife or wives. Selection is another avenue that can produce higher HIV prevalence rates in polygynous unions. Although our evidence is indirect, women who are more likely to be HIV positive (e.g., women who have been married before) more often join polygynous unions. An alternative explanation for the relatively high HIV prevalence in members of polygynous unions, namely the concurrency of sexual relationships, can be neither rejected nor confirmed with the available data.

A puzzling feature of the study site is that the highest HIV prevalence rates are found in the district where polygyny is least common (and vice versa). Using the evidence at hand, it is not possible to explain the difference in individual and aggregatelevel correlations between polygyny and HIV. ${ }^{17}$ Unobserved factors are a likely candidate, but a more intriguing hypothesis is one that implies a strong selection of HIV positive individuals into polygynous households. As we have observed in this study, this could contribute to a positive individual-level correlation between polygyny and HIV. However, if the selection is strong and the sexual networks of men and women who are in polygynous unions are sufficiently distinct from those who are in monogamous unions, they could have the potential to contain aggregate HIV prevalence rates in populations where polygyny is practiced compared to those that are more exclusively monogamous. Another factor that may help to contain the spread of HIV in populations that practice polygyny is a reduction in the frequency of intercourse in conjugal units of polygynous marriages. Such a coital dilution effect has been recognized early on in studies of differential fertility in polygynous and monogamous marriages (Musham 1956), and it might as well affect HIV incidence in serodiscordant couples with a polygynous husband.

\footnotetext{
${ }^{17}$ Incidentally, HIV prevalence is also much lower in western Africa where polygyny rates are usually much higher than in the eastern and southeastern Africa. A similar observation has been made by Frank (1992).
} 


\section{Acknowledgements}

The data for this study have been collected with the support of three NIH grants: RO1 HD372-276; RO1 HD044228 and RO1 HD/MH41713. Additional support was received from a Hewlett Foundation grant to the University of Colorado at Boulder for the African Population Studies Research and Training Program, and from the NICHDfunded University of Colorado Population Center (R21 HD51146). We are thankful to Hans-Peter Kohler, Richard Rogers, Susan Watkins, and the journal's reviewers for thoughtful comments and suggestions. 


\section{References}

Antoine, P. (2002). Les complexités de la nuptialité: de la précocité des unions féminines à la polygamie masculine en Afrique. Paris: DIAL. (Documents de Travail; DT/2002/06)

Bignami-Van Assche, S., Reniers, G. and Weinreb, A.A. (2003). An assessment of the KDICP and MDICP data quality: interviewer effects, question reliability, and sample attrition. Demographic Research S1: 29-76.

Bignami-Van Assche, S., Smith, K., Reniers, G., Anglewicz, P., Thornton, R., Chao, L.-W., Weinreb, A., Watkins, S. and Hoffman, I. (2004). Protocol for biomarker testing in the 2004 Malawi Diffusion and Ideational Change Project. Philadelphia: University of Pennsylvania. (Social Networks Project Working Papers; 6)

Caldwell, J., Caldwell, P., Ankrah, M.E., Anarfi, J.K., Agyeman, D.K., AwusaboAsare, K. and Orubuloye, I.O. (1993). African families and AIDS: context, reactions and potential interventions. Health Transition Review 3(S): 1-14.

Caldwell, J.C., Caldwell, P. and Orubuloye, I.O. (1992). The family and sexual networking in Sub-Saharan Africa: historical regional differences and presentday implications. Population Studies 46(3): 385-410.

Carael, M., Ali, M. and Cleland, J. (2001). Nuptiality and risk behavior in Lusaka and Kampala. African Journal of Reproductive Health 5(1): 83-89.

Cleland, J.G., Ali, M.M. and Capo-Chichi, V. (1999). Post-partum sexual abstinence in West Africa: implications for AIDS-control and family planning programmes. AIDS, 13(1): 125-131.

Ezeh, A. (1997). Polygyny and reproductive behavior in sub-Saharan Africa: A contextual analysis. Demography 34(3): 355-368.

Frank, O. (1992). Sexual behaviour and disease transmission in sub-Saharan Africa: Past trends and future prospects. In: Dyson, T. (ed.). Sexual behavior and networking: Anthropological and socio-cultural studies on the transmission of HIV. Liège: International Union for the Scientific Study of Population: 89-108.

Gausset, Q. (2001). AIDS and cultural practices in Africa: the case of the Tonga (Zambia). Social Science and Medicine 52(4): 509-518.

Goldman, N., Pebley, A. and Lesthaeghe, R.J. (1989). The demography of polygyny in Sub-Saharan Africa. In: Lesthaeghe, R. (ed.). Reproduction and social 
organization in Sub-Saharan Africa. Berkeley: University of California Press: 212-237.

Halton, K., Ratcliffe, A.A., Morison, L., West, B., Shaw, M., Bailey, R. and Walraven, G. (2003). Herpes simplex 2 risk among women in a polygynous setting in rural West Africa. AIDS 17(1): 97-103.

Hertrich, V. (2006). La polygamie: persistance ou recomposition? Le cas d'une population rurale du Mali. Cahiers Québécois de Démographie 35(2): 39-70.

Kelly, R.J. (2001). Determinants of HIV transmission in rural Uganda: Circumcision, concurrency and age differences in sexual partners. [PhD Thesis]. Baltimore: Johns Hopkins University.

Lagarde, E., Auvert, B., Carael, M., Laourou, M., Ferry, B., Akam, E., Sukwa, T., Morison, L., Maury, B., Chege, J., N'Doye, I. and Buve, A. (2001). Concurrent sexual partnerships and HIV prevalence in five urban communities of SubSaharan Africa. AIDS 15(7): 877-884.

Mitsunaga, T.M., Powell, A.M., Heard, N.J. and Larsen, U.M. (2005). Extramarital sex among Nigerian men: polygyny and other risk factors. Journal of Acquired Immune Deficiency Syndrome 39(4): 478-488.

Morris, M. and Kretzschmar, M. (1997). Concurrent partnerships and the spread of HIV. AIDS 11(5): 641-648.

Musham, H.V. (1956). Fertility of polygamous marriages. Population Studies 10(1): 3-16.

Nnko, S., Boerma, J.T., Urassa, M., Mwaluko, G. and Zaba, B. (2004). Secretive females or swaggering males? An assessment of the quality of sexual partnership reporting in rural Tanzania. Social Science and Medicine 59(2): 299-310.

NSO and ORC Macro. (1994). Malawi demographic and health survey 1992. Zomba, Malawi and Calverton, MD: National Statistical Office [Malawi] and ORC Macro.

NSO and ORC Macro. (2005). Malawi demographic and health survey 2004. Zomba, Malawi and Calverton, MD: National Statistical Office [Malawi] and ORC Macro.

Obare, F., Fleming, P., Anglewicz, P., Thornton, R., Martinson, F., Kapatuka, A., Poulin, M., Watkins, S. and Kohler, H.-P. (Forthcoming). Acceptance of repeat population-based voluntary counseling and testing for HIV in rural Malawi. Sexually Transmitted Infections. 
Oppong, J.R. and Kalipeni, E. (2003). Perceptions and misperceptions of AlDS in Africa. In: Kalipeni, E., Craddock, S., Oppong, J.R. and Ghosh, J. (eds.). AIDS in Africa: Beyond epidemilogy.

Orubuloye, I.O., Caldwell, J.C. and Caldwell, P. (1997). Men's sexual behaviour in urban and rural southwest Nigeria: its cultural, social and attitudinal context. Health Transition Review 7(S): 315-328.

Pebley, A.R. and Mbugua, W. (1989). Polygyny and fertility in sub-Saharan Africa. In: Lesthaeghe, R. (ed.). Reproduction and social organization in sub-Saharan Africa. Berkeley: University of California Press: 338-364.

Philipson, T. and Posner, R.A. (1995). The microeconomics of the AIDS epidemic in Africa. Population and Development Review 21(4): 835-848.

Pison, G. (1986). La démographie de la polygamie. Population 41(1): 93-122.

Potterat, J.J., Zimmerman-Rogers, H., Muth, S.Q., Rothenberg, R.B., Green, D.L., Taylor, J.E., Bonney, M.S. and White, H.A. (1999). Chlamydia transmission: concurrency, reproduction number, and the epidemic trajectory. American Journal of Epidemiology 150(12): 1331-1339.

Reniers, G. (2003). Divorce and remarriage in rural Malawi. Demographic Research S1: 175-206.

Reniers, G. (2008). Marital strategies for regulating exposure to HIV. Demography 45(2): 417-438.

Timæus, I.M. and Reynar, A. (1998). Polygynists and their wives in sub-Saharan Africa: An analysis of five Demographic and Health Surveys. Population Studies 52(2): 145-162.

Van de Walle, E. (1968). Marriage in African censuses and inquiries. In: Brass, W., Coale, A., Demeney, P., Heisel, D.F., Lorimer, F., Romaniuk, A. and Van de Walle, E. (eds.). The demography of tropical Africa. Princeton: Princeton University Press: 183-238.

Van de Walle, E. (1990). The social impact of AIDS in Sub-Saharan Africa. Milbank Quarterly 68(S1): 10-32.

Watkins, S., Zulu, E.M., Kohler, H.-P. and Behrman, J. (2003). Social interactions and HIV/AIDS in rural Africa. Rostock, Germany: Max Planck Institute for Demographic Research. 
Wawer, M.J., Gray, R.H., Sewankambo, N.K., Serwadda, D., Li, X., Laeyendecker, O., Kiwanuka, N., Kigozi, G., Kiddugavu, M., Lutalo, T., Nalugoda, F., WabwireMangen, F., Meehan, M.P. and Quinn, T.C. (2005). Rates of HIV-1 transmission per coital act, by stage of HIV-1 infection, in Rakai, Uganda. The Journal of Infectious Diseases 191(9): 1403-1409.

Westoff, C. (2003). Trends in marriage and early childbearing in developing countries. Calverton, Maryland: ORC Macro. (DHS Comparative Reports; 5) 